\title{
Pengaruh Metode Pembelajaran Mind Mapping terhadap Hasil Belajar Siswa Kelas V Sekolah Dasar Negeri 2 Sumberrejo
}

\author{
Nita Mei Ekawati'), Diana Kusumaningrum ${ }^{2)}$ \\ 1) PGSD, Universitas Islam Raden Rahmat Malang, Malang,Indonesia \\ E-mail:nitamei158@gmail.com \\ ${ }^{2)}$ PGSD, Universitas Islam Raden Rahmat Malang, Malang, Indonesia \\ E-mail:kusumadiana856@gmail.com
}

\begin{abstract}
ABSTRAK: Pembelajaran yang masih menggunakan metode konvensional di SDN 2 Sumberejo mengakibatkan rendahnya pemahaman siswa terhadap materi pelajaran, karena siswa tidak terlibat secara langsung dalam proses pembelajaran. Metode pembelajaran yang dapat meningkatkan hasil belajar siswa yaitu metode pembelajaran mind mapping. Metode mind mapping adalah cara mencatat yang kreatif, efektif, dan secara hafiah yang akan "memetakan" pikiran-pikiran kita. Penelitian ini bertujuan untuk mengetahui apakah ada pengaruh penerapan metode pembelajaran mind mapping terhadap hasil belajar siswa kelas V Sekolah Dasar Negeri 2 Sumberrejo tahun pelajaran 2018/2019. Metode penelitian yang digunakan dalam penelitian ini adalah eksperimen. Bentuk penelitian yang digunakan dalam penelitian ini adalah quasi ekperiment. Desain penelitian yang digunakan adalah nonequivalent control group designe. Instrumen penelitian yang digunakan dalam penelitian ini berupa lembar pretest, lembar posttest, lembar validasi dan pedoman wawancara. Teknik pengumpulan data menggunakan tes objektif (pilihan ganda) sebanyak 15 soal. Teknik pengambilan sampel menggunakan sampling jenuh dimana seluruh anggota populasi digunakan sebagai sampel penelitian. Penelitian ini dilaksanakan di SDN 2 Sumberrejo Kecamatan Gedangan Kabupaten Malang, semester genap tahun pelajaran 2018/2019. Jumlah sampel penelitian 41 siswa terdiri dari satu kelas kelompok eksperimen dan satu kelas kelompok kontrol. Hasil penelitian menunjukkan bahwa; (1) terdapat pengaruh yang signifikan terhadap hasil belajar siswa sebelum diberi pelakuan dan sudah diberi perlakuan dengan menerapkan metode pembelajaran mind mapping; (2) ada perbedaan hasil belajar siswa kelas $\mathrm{V}$ antara penerapkan metode pembelajaran mind mapping dan metode pembelajaran konvesional. Hal tersebut juga dibuktikan pada uji independent samples $t$-test yang menunjukkan, jika dilihat dari signifikan lebih kecil dari 0.05, yaitu 0.007. Berdasarkan hasil analisis data dan pembahasan, maka kesimpulan yang dapat diambil dari penelitian ini adalah penerapan metode mind mapping dapat meningkatkan hasil belajar siswa.
\end{abstract}

Keywords: Mind Mapping, Hasil Belajar

\section{PENDAHULUAN}

Hasil belajar merupakan salah satu indikator yang dapat digunakan untuk mengukur keberhasilan belajar seseorang [1]. Menurut [2] ada banyak faktor yang mempengaruhi pencapaian nilai hasil belajar siswa, baik berasal dalam diri siswa (internal) maupun dari lingkungan luar (eksternal). Faktor internal terkait dengan disiplin, respon dan motivasi siswa, sementara faktor eksternal berasal dari lingkungan belajar, kreatifitas pemilihan media belajar oleh guru serta metode pembelajaran. [1] berpendapat bahwa pemilihan metode pembelajaran yang tepat akan membawa suasana belajar yang menyenangkan dan memungkinkan siswa untuk mengembangkan kreatifitas. Suasana belajar yang menyenangkan akan membawa dampak pada motivasi belajar dan disiplin yang meningkat. Motivasi yang tinggi menjadi salah satu faktor penentu keberhasilan siswa dalam mencapai hasil belajar yang terbaik.

Berdasarkan observasi di SD Negeri 2 Sumberrejo pada kelas VA dan VB, didapat hasil observasi bahwa guru masih menggunakan metode konvensional dengan menggunakan cara mencatat ulang materi. Kebanyakan dari materi pelajaran yang kompleks dan membutuhkan pemahaman yang mendalam sangat sukar dipahami oleh siswa dan siswa cenderung belajar menghafal, menyebabkan materi tersebut tidak tersimpan dalam ingatan siswa dan siswa cenderung 
tidak berminat untuk mempelajari materi tersebut. Hasil observasi juga menunjukkan ada beberapa siswa yang aktif dalam pembelajaran, misalnya ada yang aktif bertanya tetapi ada juga siswa yang enggan bertanya karena malu dan takut salah. Guru harus menggunakan metode pembelajaran yang tepat agar siswa mendapat dampak positif ketika melakukan pembelajaran di kelas yang akan berpengaruh terhadap hasil belajar siswa.

Selain observasi, peneliti juga melakukan wawancara dengan guru kelas VA dan VB dilakukan pada hari yang sama. Berdasarkan hasil wawancara dapat disimpulkan guru masih sering kesulitan menggunakan metode pembelajaran yang berinovasi dan lebih suka menggunakan metode konvensional seperti ceramah dilanjutkan mencatat ulang materi yang sudah disampaikan oleh guru, menurut guru metode tersebut membuat siswa tidak ramai. Guru menuturkan jika beliau pernah menggunakan metode diskusi kelompok tetapi dalam pelaksanaan memakan waktu yang lama sehingga apabila diterapkan pada pembelajaran tidak bisa efektif.

Siswa juga memiliki kemampuan yang berbeda-beda dalam menangkap atau memahami materi pelajaran, ada yang mudah memahami materi dan ada juga siswa yang kesulitan dalam memahami materi yang disampaikan oleh guru, sehingga ada siswa yang mendapat nilai dibawah KKM atau kurang dari 75. Terdapat 14 siswa dari 20 siswa kelas VA yang mendapat nilai dibawah KKM, dan 12 siswa dari 21 siswa kelas VB yang mendapat nilai dibawah KKM. Berdasarkan hasil wawancara dan observasi pada guru kelas VA dan VB maka perlu dicari solusi untuk meningkatkan hasil belajar kognitif siswa dalam pembelajaran khususnya untuk pembelajaran tematik kelas V tema 7 di SD Negeri 2 Sumberrejo. Beberapa cara untuk meningkatkan hasil belajar kognitif siswa menurut [3] dalam penelitiannya yaitu; 1) menumbuhkan lingkungan belajar yang kreatif dan kondusif, 2) menghubungkan pelajaran dengan pengalaman siswa, 3) memberi hadiah bagi siswa yang berprestasi, 4) menggunakan alat peraga, 5) belajar dan bermain, serta 6) menggunakan metode mengajar yang bervariasi.

Salah satu metode pembelajaran yang dapat meningkatkan hasil belajar siswa yaitu metode pembelajaran mind mapping. Menurut [4] metode mind mapping adalah cara mencatat yang kreatif, efektif, dan secara hafiah yang akan "memetakan" pikiran-pikiran kita. [5] berpendapat mind mapping (peta pikiran) merupakan diagram yang digunakan untuk mewakili kata-kata, ide, dan konsep lainnya yang disusun disekitar ide utama. [6] dalam penelitiannya mengemukakan pengertian peta pikiran atau mind mapping adalah metode pembelajaran yang dirancang untuk mengembangkan pengetahuan siswa dengan kegiatan kreatif menyusun ide-ide pokok dari sebuah konsep menjadi sebuah peta pikiran yang mudah dipahami oleh siswa.

Peneliti dapat mengambil kesimpulan bahwa mind mapping adalah suatu cara yang memungkinkan untuk mengeksplorasi seluruh kemampuan otak kita untuk keperluan berfikir dan belajar. Melalui mind mapping, siswa tidak lagi dituntut untuk selalu mecatat tulisan yang ada di papan tulis atau yang disampaikan oleh guru secara keseluruhan. Siswa akan mengetahui inti masalah, kemudian membuat peta pikirannya masing-masing sesuai dengan kreativitas mereka. Penggunaan metode mind mapping dapat meningkatkan hasil belajar siswa, hal ini dapat diperkuat dengan adanya fakta dilapangan berupa penelitian-penelitian terdahulu yang menujukkan bahwa metode pemelajaran mind mapping memberikan pengaruh terhadap hasil belajar siswa, pengaruh tersebut dapat dilihat dari perbedaan hasil belajar siswa menggunakan metode mind mapping dan metode konvensional [7], berpengaruh positif terhadap hasil belajar kognitif siswa yang signifikan antara metode mind mapping dan metode konvensional [8] serta metode mind mapping dapat meningkatkan konsentrasi dan hasil belajar siswa [9]

Metode pembelajaran mind mapping dapat membantu kita dalam berbagai hal, seperti yang disampaikan [4] metode pembelajaran mind mapping dapat membantu kita untuk: (1) memberi pandangan menyeluruh pokok masalah atau area yang luas, (2) memungkinkan kita merencanakan rute atau memuat pilihan-pilihan dan mengetahui ke mana kita akan pergi dan dimana kita berada, (3) mengumpulkan sejumlah besar data di satu tempat, (4) mendorong pemecahan masalah dengan memberikan kita melihat jalan-jalan terobosan kreatif baru, (5) menyenangkan untuk dilihat, dibaca, dicerna, dan diingat. Berdasarkan uraian di atas, maka penulis bermaksud melakukan penelitian mengenai "Pengaruh Penerapan Metode Pembelajaran Mind Mapping Terhadap Hasil Belajar Siswa Kelas V Sekolah Dasar Negeri 2 Sumberrejo Tahun Pelajaran 2018/2019"..

\section{METODE}

Metode penelitian yang digunakan dalam penelitian ini adalah eksperimen. Bentuk penelitian yang digunakan dalam penelitian ini adalah quasi ekperiment. Desain penelitian yang digunakan adalah nonequivalent control group designe. Rancangan ini terdapat dua kelompok yang dipilih tidak secara random. Rancangan tersebut dapat digambarkan sebagai berikut:

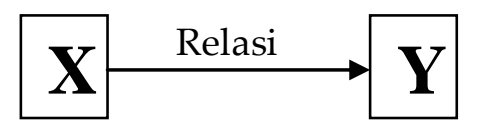

\section{Gambar 1 Struktur hubungan $X, Y$}

Populasi dalam penelitian ini adalah siswa kelas V SD Negeri 2 Sumberrejo kecamatan Gedangan yang berjumlah 41 siswa. Teknik pengambilan sampel menggunakan sampling jenuh dimana seluruh anggota populasi digunakan sebagai sampel penelitian. Sampel dalam penelitian ini yaitu siswa kelas VA sebagai kelompok eksperimen yang terdiri 20 siswa dan siswa kelas VB sebagai kelompok kontrol yang terdiri 21 siswa.

Instrumen penelitian yang digunakan dalam penelitian ini berupa lembar pretest, lembar posttest, lembar validasi dan pedoman wawancara. Jenis data yang digunakan penelitian ini adalah data kuantitatif berupa hasil belajar siswa yang diperoleh melalui tes. 
Macam tes yang digunakan dalam penelitian ini adalah tes formatif yang digunakan untuk mengukur pencapaian setelah melakukan proses belajar mengajar. Pretest dan posttest yang digunakan dalam penelitian ini adalah tes objektif (pilihan ganda) bejumlah 15 butir dengan soal yang sama, namun berbeda pada urutan soal antara pretest dengan posttest. Soal pretest dan postet yang diberikan berdasarkan revisi Taksonomi Bloom yang mengacu pada pengetahuan, pemahaman, penerapan, analisis, evaluasi, dan mencipta. Selanjutnya, kedua data hasil belajar siswa tersebut diuji statistik untuk mengetahui apakah ada pengaruh penerapan metode pembelajaran mind mapping terhadap hasil belajar siswa..

\section{HASIL DAN PEMBAHASAN}

Penelitian ini dilaksanakan di SD Negeri 2 Sumberrejo Kecamatan Gedangan Kabupaten Malang pada tanggal 02 Mei sampai tanggal 03 Mei 2019. Penelitian ini bertujuan untuk mengetahui pengaruh penerapan metode pembelajaran mind mapping terhadap hasil belajar siswa kelas V SD Negeri 2 Sumberrejo. Hasil belajar yang dimaksud adalah hasil belajar kognitif dan yang diukur dengan cara pemberian soal pretest dan posttets. Pretest dan posttest digunakan untuk mengetahui perbedaan hasil belajar siswa sebelum dan sesudah perlakuan di kelas eksperimen dan kelas kontrol. Selain itu, data hasil pretest dan posttest digunakan sebagai data untuk menguji normalitas dan homogenitas data serta untuk menguji hipotesis penelitan. Uji normalitas dan uji homogenitas dapat dilihat pada tabel dibawah ini:

Tabel 1 Uji Normalitas

\begin{tabular}{llllllll}
\hline \multicolumn{1}{c}{ Kelas } & \multicolumn{3}{c}{ Kolmogorov- } & \multicolumn{3}{c}{ Shapiro-Wilk } \\
\cline { 3 - 8 } & & $\begin{array}{l}\text { Statis } \\
\text { tic }\end{array}$ & Df & Sig. & $\begin{array}{l}\text { Statis } \\
\text { tic }\end{array}$ & df & Sig. \\
\hline Hasil_ & $\begin{array}{l}\text { Eksperi } \\
\text { Belajar }\end{array}$ & .165 & 20 & .157 & .935 & 20 & .193 \\
& $\begin{array}{l}\text { Ken } \\
\text { Kontrol }\end{array}$ & .138 & 21 & .200 & .931 & 21 & .142 \\
\hline
\end{tabular}

Sumber: Hasil analisis menggunakan SPSS 20

Uji normalitas pada tabel 1 Shapiro-Wilk mencul nilai signifikan untuk kelas ekperimen 0,193 dan kelas kontrol 0,142 . Hasil uji normalitas data pretest menunjukan bahwa signifikasi pada kelas kontrol dan kelas eksperimen lebih besar dari taraf signifikan 0,05 , maka persebaran data kelas eksperimen dan kelas kontrol dinyatakan normal.

Tabel 2 Uji Homogenitas

\begin{tabular}{lccc}
\hline $\begin{array}{c}\text { Levene } \\
\text { Statistic }\end{array}$ & df1 & df2 & Sig. \\
\hline 2.932 & 1 & 39 & .095 \\
\hline Sumber : & Hasil analisis meng munakan & SPSS 20
\end{tabular}

Berdasarkan tabel 2 uji homogenitas dapat diketahui bahwa nilai signifikasi 0,095 lebih besar dari pada taraf signifikan 0,05, jadi dapat disimpulkan bahwa data homogen. Setelah data berdistribusi normal dan homogen baru dilakukan uji hipotesis, dengan hipotesis sebagai berikut :

$\mathrm{H}_{0}$ : Tidak ada perbedaan yang signifikan antara hasil belajar siswa kelas VA dan VB menggunakan metode pembelajaran mind mapping.

$\mathrm{H}_{1}$ : Ada perbedaan hasil belajar yang signifikan pada kelas VA dan VB menggunakan metode pembelajaran mind mapping

Hasil analisis uji hipotesis dapat dilihat pada tabel 3. Hasil tersebut menunjukan bahwa $H_{o}$ ditolak dan $H_{1}$ diterima. Sehingga dapat disimpulkan bahwa ada perbedaan hasil belajar siswa kelas VA dan VB menggunakan metode pembelajaran mind mapping.

Tabel 3 Uji Hipotesis

\begin{tabular}{|c|c|c|c|c|c|c|c|c|c|c|}
\hline \multicolumn{11}{|c|}{ Independent Samples Test } \\
\hline & & \multicolumn{2}{|c|}{$\begin{array}{l}\text { Levene's Test } \\
\text { for Equality } \\
\text { of Variances }\end{array}$} & \multicolumn{7}{|c|}{ t-test for Equality of Means } \\
\hline & & \multirow[t]{2}{*}{$\mathrm{F}$} & \multirow[t]{2}{*}{ Sig. } & \multirow[t]{2}{*}{$\mathrm{T}$} & \multirow[t]{2}{*}{ Df } & \multirow[t]{2}{*}{$\begin{array}{l}\text { Sig. (2- } \\
\text { tailed) }\end{array}$} & \multirow[t]{2}{*}{$\begin{array}{l}\text { Mean } \\
\text { Differ } \\
\text { ence }\end{array}$} & \multirow{2}{*}{$\begin{array}{l}\text { Std. } \\
\text { Error } \\
\text { Differe } \\
\text { nce }\end{array}$} & \multicolumn{2}{|c|}{$\begin{array}{c}95 \% \text { Confidence } \\
\text { Interval of the } \\
\text { Difference }\end{array}$} \\
\hline & & & & & & & & & Lower & Upper \\
\hline \multirow{2}{*}{$\begin{array}{l}\text { Hasil_B } \\
\text { elajar }\end{array}$} & $\begin{array}{l}\text { Equal variances } \\
\text { assumed }\end{array}$ & 6.148 & .018 & 2.865 & 39 & .007 & 9.174 & 3.202 & 2.697 & 15.650 \\
\hline & $\begin{array}{l}\text { Equal variances not } \\
\text { assumed }\end{array}$ & & & 2.895 & 34.296 & .007 & 9.174 & 3.169 & 2.736 & 15.611 \\
\hline
\end{tabular}


Rekapitulasi hasil belajar siswa dengan penerapan metode mind mapping dan metode konvensioanal/ceramah disajikan dalam tabel 4 berikut:

Tabel 4 Rekapitulasi Hasil Belajar Siswa Kelas V

\begin{tabular}{lllll}
\hline \multirow{2}{*}{ Statistika } & \multicolumn{2}{c}{$\begin{array}{c}\text { Kelas } \\
\text { Eksperimen }\end{array}$} & & Kelas Kontrol \\
& Pretest & Posttest & Pretest & Posttest \\
\hline $\begin{array}{l}\text { Banyak peserta } \\
\text { didik }\end{array}$ & \multicolumn{2}{c}{20} & 21 \\
\hline Nilai Minimum & 40 & 73 & 47 & 60 \\
\hline Nilai Maksimal & 87 & 100 & 80 & 100 \\
\hline Rata-rata & 64,65 & 86,65 & 64,10 & 77,48 \\
\hline Presentase & $65 \%$ & $87 \%$ & $64 \%$ & $77 \%$ \\
\hline
\end{tabular}

Berdasarkan tabel 4 dapat dikemukakan hasil belajar siswa antara penerapan metode mind mapping dengan konveksional/cerama adalah bahwa pembelajaran menggunakan metode mind mapping lebih baik dari metode ceramah. Perbedaan hasil belajar siswa bukan dihasilkan dari suatu kebetulan, maliankan disebabkan oleh hal-hal sebagai berikut; penggunaan metode pembelajaran yang inovasi yaitu metode mind mapping berpengaruh besar dalam peningkatan hasil belajar siswa, karena pembelajaran lebih menyenangkan, catatan dengan metode mind mapping lebih terfokus pada inti materi, siswa lebih mudah mencari catatan dan catatan lebih jelas, mudah melihat gambar keseluruhan, dan pengkajian materi bisa lebih cepat. Hal ini sejalan dengan hasil penelitian [10]berjudul "Penerapan Metode Mind Map Pohon Jaringan untuk Meningkatkan Hasil Belajar Siswa pada Materi Tokoh Kerajaan Islam di Indonesia" bahwa hasil belajar telah melebihi target dan dapat meningkatkan hasil belajar siswa. Penelitian yang senada juga dilakukan oleh [11] dengan judul "Pengaruh Implementasi Metode Mind Mapping Terhadap Hasil Belajar IPS Ditinjau dari Minat Siswa Kelas IV SD Sathya SAI Denpasar" didapat hasil dengan menggunakan metode pembelajaran mind mapping berpengaruh lebih baik terhadap hasil belajar IPS dengan rata-rata skor hasil belajar siswa yang mengikuti metode pembelajaran mind mapping adalah 73,05 sementara rata-rata skor hasil belajar siswa yang mengikuti metode pembelajaran konvensional adalah 60,63. [12] pada penelitiannya membuktikan hasil yang sama dengan judul "Penerapan Metode Mind Mapping untuk Meningkatkan Minat dan Hasil Belajar IPA Siswa Kelas V SD N Balangan 1" dapat membuktikan bahwa pembelajaran menggunakan metode mind mapping dapat meningkatkan minat hasil belajar siswa $36 \%$.

Pembelajaran dengan mengunakan metode mind mapping memiliki serangkaian langkah-langkah yang sifatnya menjadikan seluruh siswa terlibat dalam proses berpikir secara individual untuk menghasilkan ide-ide kreatif apa yang mereka pelajari dan apa yang mereka rencanakan. Hal ini sejalan dengan pernyataan [13] yang menyatakan mind napping adalah cara baru untuk belajar dan berlatih yang cepat dan ampuh serta dapat membantu catatan yang tidak membosankan. Guru meminta siswa untuk membuat peta pikiran bertujuan agar siswa dapat menemukan kemudahan untuk mengidentifikasi secara jelas dan kreatif apa yang mereka rencanakan dan mereka pelajari.

Pembelajaran dengan menggunakan metode mind mapping dapat dilakukan dengan langkah-langkah sebagai berikut: Pertama siswa diarahkan untuk menulis gagasan utamanya di tengah-tengah kertas dan dilingkupi dengan lingkaran, persegi, atau bentuk lain (siswa diharuskan menulis secara rapi dengan menggunaka huruf-huruf kapital sehingga terlihat menonjol dan berbeda dengan yang lain). Kedua siswa diminta untuk menambahkan sebuah cabang yang keluar dari pusatnya untuk setiap poin (langkah ini menggunakan warna yang berbeda untuk tiap-tiap cabang dan siswa menggambar dengan hal-hal yang berhubungan dengan kehidupan sehari-harinya). Ketiga siswa menuliskan kata kunci dan menggaris bawahi kata-kata tiap cabang yang dikembangkannya (kata kunci adalah katakata yang menyampaikan inti sebuah gagasan dan memicu ingatan siswa jika siswa menggunakan singkatan maka siswa dengan mudah segera mengingat artinya selama bermingguminggu setelahnya). Keempat siswa menambahkan simbolsimbol dan ilustrasi-ilustrasi untuk mendapatkan ingatan yang lebih baik.

Metode pembelajaran mind mapping dapat meningkatkan hasil belajar siswa karena kelebihannya. Kelebihan mind mapping menurut Herdin dalam [4] pertama siswa dapat fokus di tengah sesuai dengan cara otak bekerja secara terpusat lalu menyebar ke segala petunjuk arah secara bebas. Kedua siswa dapat mudah memahami sesuatu yang sistematis, sederhana dan menyenagkan. Ketiga siswa akan mengingat dengan mudah semua informasi yang disukai. Keempat siswa akan mengingat kembali dalam jangka panjang atas semua yang dipelajari melalui imajinasi dan asosiasi yang tersimpan dengan baik di dalam otak.

Berbeda dengan kelompok eksperimen yang menerapkan pembelajaran mind mapping, kelompok kontrol menerima pembelajaran yang biasa dilakukan guru yaitu ceramah. [14] menyatakan bahwa pembelajaran dengan metode cerama merupakan suatu cara penyampain pelajaran melalui penuturan. Selama kegiatan pembelajaran berlangsung siswa menerima materi pelajaran dari guru yang menggunakan metode ceramah. Siswa diposisikan sebagai objek pasif penerima pembelajaran. Mereka menggunakan kemampuan mengingat untuk memahami materi pelajaran. Hal ini menyebabkan materi yang diperoleh siswa sebatas hafalan dan ingatan tanpa diikuti kemampuan kognitif lain yaitu memahami, mengaplikasikan, menganalisis.

\section{KESIMPULAN}

Berdasarkan hasil analisis data dan pembahasan, maka kesimpulan yang dapat diambil dari penelitian ini adalah penerapan metode mind mapping dapat meningkatkan hasil belajar siswa. Peningkatan hasil belajar dapat dibuktikan pada nilai rata-rata hasil belajar siswa kelas eksperimen 86,65 dengan persentase $87 \%$ dan nilai rata-rata hasil belajar kelas kontrol 77,48 dengan presentase $77 \%$. Hasil pengujian uji Independent Sampel $t$ Test menunjukkan nilai sig (2-tailed) $0,007,(0,007<0,05)$ sehingga $\mathrm{H}_{\mathrm{o}}$ ditolak $\mathrm{H}_{1}$ diterima dan dapat disimpulkan bahwa metode mind mapping dapat 
mempengaruhi hasil belajar siswa kelas V SD Negeri 2 Sumberrejo Kecamatan Gedangan Kabupaten Malang pada materi tema 7 subtema 3 pembelajaran 6 matapelajran PPKn dan SBdP.

Berdasarkan penelitian yang telah dilakukan, penulis memiliki saran sebagai berikut: Bagi siswa, diharapkan menerapkan metode mind mapping sebagai kegiatan mencatat sehari-hari yang menyenangkan, memudahkan pemahaman siswa dan catatan lebih terfokus pada inti materi. Bagi guru, diharapkan menerapkan metode mind mapping dalam kegiatan pembelajaran di kelas karena mind mapping lebih efektif terhadap hasil belajar kognitif siswa dibandingkan metode yang biasa digunakan guru yaitu ceramah dan tanya jawab. Bagi peneliti selanjutnya, penelitian ini dapat digunakan sebagai bahan acuan dan sumber informasi untuk penelitian yang serupa dengan metode pembelajaran yang sama, sehingga dapat dikembangkan menjadi lebih baik lagi. Bagi sekolah, pelaksanaan metode mind mapping dapat diterapkan di sekolah dengan baik. Metode tersebut sangat menarik dan dapat meningkatkan hasil belajar dan kreativitas siswa. Sekolah diharapkan mendukung pelaksanaan metode pembelajaran baru yang ingin diterapkan guru seperti metode mind mapping.

\section{UCAPAN TERIMAKASIH}

Kami ingin berterimakasih kepada Universitas Islam Raden Rahmat Malang yang telah memberikan dukungan sehingga penelitian ini dapat dilaksanakan dan diselesaikan dengan baik.

\section{REFERENCES}

[1] Maisaroh dan Rostrieningsih. 2010. Peningkatan Hasil Belajar Siswa Dengan Menggunakan Metode Pembelajaran Active Learning Tipe Quiz Team Pada Mata Pelajaran Keterampilan Dasar Komunikasi Di SMK Negeri 1 Bogor, Jurnal Ekonomi \& Pendidikan. Volume 8 Nomor 2.

[2] Munadi, Yudi. 2008. Media Pembelajaran. Jakarta. Gaung Persada (GP) Press.

[3] Pamungkas, Tri LA. 2013. Peningkatan Kretivitas dan Kemampuan Pemecahan Masalah Matematika Melalui Model Pembelajaran Creative Problem Solving. Skripsi. Universitas Muhammadiyah Surakarta.

[4] Buzan, Tony. 2008. Buku Pintar Mind Map. Jakarta. PT Gramedia Pustaka Utama.

[5] Adilah, Nida. 2017. Perbedaan Hasil Belajar Ipa melalui Penerapan Metode Mind mapping dengan Metode Ceramah. Journal of Primary Education. Volume 1. Nomor 1.

[6] Darusalam, Rijal. 2014. Penerapan Metode Mind Mapping (Peta Pikiran) untuk Meningkatkan Kemampuan Berpikir Kreatif Matematika Siswa SMP. Jurnal Ilmiah Program Studi Matematika STIKIP Siliwangi Bandung. Volume 3. Nomor 2.

[7] Mawarni, Luvirta Tiyas. 2017. Pengaruh Metode Mind Mapping Terhadap Hasil Belajar Matematika Siswa
Kelas IV SD Negeri 1 Tambah Dadi. Skripsi. Universitas Lampung.

[8] Rumanti, Nur Dani. 2014. Pengaruh Penerapan Mind Map Terhadap Hasil Belajar Kognitif Ilmu Pengetahuan Alam Pada Siswa Kelas IV SD Gugus Hasanuddin Kecamatan Mertoyudan Kabupaten Magelang. Skripsi. Universitas Negeri Yogyakarta.

[9]Azizah, Sulis Nur. 2015. Penerapan Metode Mind Mapping Siswa Kelas V SD Negeri Jomblangan Banguntapan Bantul. Skripsi. Universitas Negeri Yogyakarta.

[10]Hermawan, Irwan., Kurnia, Dadang., dan Sudin, Ali. 2016. Penerapan Metode Mind Map Pohon Jaringan untuk Meningkatkan Hasil Belajar Siswa pada Materi Tokoh Kerajaan Islam di Indonesia. Jurnal Pena Ilmiah. Volume 1 Nomor 1.

[11]Darmayoga, I Wayan. Lasmawan, I Wayan. Marhaeni, A.A.I.N. 2013. Pengaruh Implementasi Metode Mind Mapping Terhadap Hasil Belajar IPS Ditinjau dari Minat SIswa Kelas IV SD Sathya SAI Denpasar. Jurnal Program Pascasarjanah Universitas Pendidikan Ganesha Jurusan Pendidikan Dasar. Volume 3 Nomor 1.

[12]Safiri, Dyah. 2016. Penerapan Metode Mind mapping untuk Meningkatkan Minat dan Hasil Belajar IPA Siswa Kelas V SD N Balangan 1. Jurnal Pendidikan Guru Sekolah Dasar. Volume 5 nomor 3

[13]Buzan, Tony. 2007. Buku Pintar Mind Map Untuk Anak. Jakarta. PT Gramedia Pustaka Utama.

[14] Sumiati dan Asra. 2009. Metode Pembelajaran. Bandung: CV Wacana Prima. 